\title{
The Figurative Foundations of Rousseau's Politics
}

\author{
Emma Planinc* \\ Program of Liberal Studies, University of Notre Dame \\ ${ }^{*}$ Corresponding author. E-mail: eplaninc@nd.edu
}

Rousseau claims that the lawgiver must "persuade without convincing," binding this legislative communication to the "first language," which would, Rousseau writes, "persuade without convincing, and depict without arguing." Drawing on a wide range of contextual sources, I show that this first language of Rousseau's is figurative, imagistic, and modeled on ancient Egyptian hieroglyphs, which William Warburton claimed were "the uniform voice of nature" in his Divine Legation of Moses. More importantly, I demonstrate that Rousseau was himself using this lost ancient language to provide a figuration of his own: the "illusory image" of natural man. Through the Second Discourse, men could be persuaded that they were by nature free, preparing the way for a social contract in which they could legitimately give themselves law. This is an image that I argue has been effectively persuasive up to the present day-and our politics, like Rousseau's, thus seemingly rests on figurative foundations.

You are feared, you are too free, and one is afraid that we might want to be as free as you.

\section{Moultou to Rousseau ${ }^{1}$}

In On the Social Contract, Jean-Jacques Rousseau claims that any legitimate state requires a lawgiver: a figure of "superior intelligence" who is not of the state, but will supply its law; "the mechanic who invents the machine." ${ }^{2}$ The lawgiver is described as wielding a seemingly boundless power of "establish[ing] a people's institutions ... [and] changing, so to speak, human nature; of transforming each individual, who by himself is a complete and solitary whole, into a part of a greater whole from which that individual receives as it were his life and being." 3 To this great power, Rousseau adds a great difficulty: to achieve this transformation, the

effect would have to become the cause. The social spirit which ought to be the work of that institution, would have to preside over the institution itself, and

\footnotetext{
${ }^{1}$ From Helena Rosenblatt's Rousseau and Geneva (Cambridge, 2003), 273 (Correspondance complète de Jean-Jacques Rousseau, ed. R. Leigh (Geneva, 1965-91) 1899, Volume XI).

${ }^{2}$ Rousseau, SC II vii, 190-91; OC III, 381. For all references to the Social Contract, and to the Second Discourse, I use John T. Scott's Major Political Writings (Chicago, 2012). The French is also consulted. They are cited SC and SD respectively, followed by the corresponding references to the Oeuvres Completes in the form OC, volume number, page number. Jean-Jacques Rousseau, Oeuvres complètes, 5 vols. (Paris, 1965-95).

${ }^{3}$ Rousseau, SC II vii, 191; OC III, 381.

(C) The Author(s), 2022. Published by Cambridge University Press. This is an Open Access article, distributed under the terms of the Creative Commons Attribution licence (https://creativecommons.org/licenses/by/4.0/), which permits unrestricted re-use, distribution, and reproduction in any medium, provided the original work is properly cited.
} 
men would have to be prior to the laws what they are to become through the laws. Hence, therefore, since the lawgiver can use neither force nor reasoning, he must of necessity have recourse to an authority of a different order which might be able to motivate without violence, and persuade without convincing. ${ }^{4}$

The lawgiver is tasked with attending to this persuasion which does not convince "in secret," for this is a kind of law (the fourth type of law discussed by Rousseau at the end of Book II of the Social Contract) that is "unknown to our politicians." This secret persuasion, Rousseau claims, is the most "unshakable keystone" of the state, and "is not engraved on marble or bronze, but in the hearts of the citizens." As John Scott writes, the lawgiver's power is thus "extralegal," attending "to the cultural affective basis of the state" through a form of "non-rational persuasion." Christopher Kelly highlights that "for Rousseau, true citizenship is based on neither coercion nor reason, but feeling"; Bryan Garsten sees Rousseau's call to "persuade without convincing" as a suggestion to "reconstitute individuals from within"; and Avi Lifschitz argues that this means that lawgivers must mold opinions "much more deeply than via rational argumentation."

The allocation of lawmaking power to a nonrational capacity to persuade (sway) without convincing (provide reasonable argument) carries with it the suggestion that politics is the site of falsehood over truth, and of storytelling over fact founding. If it is also necessary for the lawgiver to make men "obey with freedom and bear the yoke of public felicity with docility," he becomes a dark figure in Rousseau's work -foreshadowing, some believe, the excesses of the Jacobin Terror of the French Revolution, and laying the groundwork for the worst forms of "nonrational" politics in the modern world. ${ }^{10}$ Kelly concedes that Rousseau's work potentially leaves too much room for "irrational fanaticism" in the "apparently undemocratic focus on the legislator." 11 Garsten, more radically, sees a direct link between Rousseau's "nonrational forms of persuasion and fanaticism," offering an alluring "rhetoric of prophetic nationalism" for Rousseau's own time and beyond. ${ }^{12}$

\footnotetext{
${ }^{4}$ Rousseau, SC II vii, 192-3; OC III, 383, my emphasis.

${ }^{5}$ Rousseau, SC II xii, 202; OC III, 394.

${ }^{6}$ Rousseau, SC II xii, 203, 202; OC III, 394.

${ }^{7}$ John T. Scott, "Rousseau and the Melodious Language of Freedom," Journal of Politics 59/3 (1997), $803-29$, at $824-5$.

${ }^{8}$ Christopher Kelly, “To Persuade without Convincing: The Language of Rousseau's Legislator," American Journal of Political Science 31/2 (1987), 321-35, at 327; Bryan Garsten, "Persuading without Convincing: Rousseau," in Garsten, Saving Persuasion (Cambridge, MA, 2009), 55-83, at 57; Avi Lifschitz, "How to Do Things with Signs: Rousseau's Ancient Performative Idiom," History of Political Thought 37 (2016), 46-63, at 49.

${ }^{9}$ Rousseau, SC II vii, 193; OC III, 383.

${ }^{10}$ See, for example, Waller Newell, Tyranny: A New Interpretation (Cambridge, 2013), 450. Newell is the most recent thinker to make this claim, though certainly not the first. Bertrand Russell also draws a link from Rousseau to Robespierre to Hitler: Bertrand Russell, A History of Western Philosophy and Its Connection with Political and Social Circumstances from the Earliest Times to the Present Day (New York, 1945). For a recent discussion of this argument also see Anthony Gottlieb, The Dream of Enlightenment: The Rise of Modern Philosophy (New York, 2016).

${ }^{11}$ Kelly, "To Persuade Without Convincing," 333

${ }^{12}$ Garsten, Saving Persuasion, 58.
} 
Fanaticism and prophesy are linked to Rousseau's seeming reliance on the powers of religion to effect this transformation of human hearts, and of the political order. Rousseau writes that the legislator can put his secret law "into the mouths of immortals, in order to motivate by divine authority those who could not be swayed by human prudence," referring to Moses and Muhammed as exemplars. ${ }^{13}$ This shows, Kelly claims, that Rousseau "sees religion as the major tool of the legislator's persuasion." 14 Ronald Beiner also claims that Rousseau is the originator of the idea of a "civil religion" because he was so convinced that "a state has never been founded without religion serving as its base." ${ }^{15}$ Rousseau concludes his discussion of the lawgiver citing the authority of William Warburton, author of The Divine Legation of Moses (1737-41) ${ }^{16}$ : "one need not conclude from all this with Warburton that among us politics and religion have a common goal, but that at the origin of nations the one serves as an instrument of the other."

Most commentators believe that Rousseau's use of The Divine Legation to close the discussion of the lawgiver is a cursory nod to something Rousseau wants to say about the relationship of religion to politics-with Warburton supplying some justification for the secret, prophetic, and religious powers of a founder (Moses) serving as an example for the future lawgiver, while setting up a disagreement that Rousseau wants to assert about religion later in the Social Contract. ${ }^{18}$ I argue, however, that Warburton's influence on Rousseau is far from cursory. The reference to Warburton links Rousseau's political work significantly to Rousseau's Essay on the Origin of Languages, and opens up a whole imaginative and interpretive landscape with regard to what he means when he says one can "persuade without convincing." Like many of his contemporaries-Du Bos, Condillac, and Diderot, to name only a few of the key players in France-Rousseau was interested in investigating the origins and operations of language. Rousseau's intellectual world was saturated with this philosophical inquiry; as Hans Aarsleff writes, "it is common knowledge that the eighteenth century was vitally interested in the origin of language."19

In what follows I will establish the overall eighteenth-century French context in which Rousseau was operating when thinking through theories of language and persuasion, but I also want to make the claim that Warburton's Divine Legation of Moses was of special importance to Rousseau's own thinking, at least as a point of inspiration. While many philosophes and their predecessors were consumed with questions of rhetoric, the origins of language, and linguistic historical transformation, Warburton saw these issues as wedded to political power and

\footnotetext{
${ }^{13}$ Rousseau, SC II vii, 193; OC III, 383.

${ }^{14}$ Kelly, “To Persuade without Convincing," 324.

${ }^{15}$ Ronald Beiner, Civil Religion (Cambridge, 2011), 11-12.

${ }^{16}$ William Warburton, The Divine Legation of Moses, Demonstrated on the Principles of a Religious Deist, from the Omission of the Doctrine of a Future State of Rewards and Punishments in the Jewish Dispensation, vol. 1, Bks I-III (1737-8); vol. 2, Bks IV-VI (1741).

${ }^{17}$ Rousseau, SC II vii, 193-4; OC III, 384.

${ }^{18}$ One notable exception here is the attention paid to this relationship (between Rousseau and Warburton) in David Lay Williams's Rousseau's Social Contract (Cambridge, 2014).

${ }^{19}$ Hans Aarsleff, From Locke to Saussure: Essays in the Study of Language and Intellectual History (Minneapolis, 1982), 147. This is from the chapter that is a reprint of the essay "The Tradition of Condillac," in Dell Hynes, ed., Studies in the History of Linguistics (Bloomington, 1974), 93-156.
} 
legislation. And while many who studied language and persuasion saw the capacity of words and expression to move peoples' passions and make them feel or see things, Rousseau, following Warburton, saw that this also meant one could move people transformatively - that is, a certain kind of (legislative) language might have the ability to make people see, and thus create, themselves anew in the world. As Sophia Rosenfeld has argued, while Condillac and Diderot, for example, also saw a kind of "lost language of primal eloquence," it was "Rousseau [who] turned his attention to one aspect of the discussion that both Condillac and Diderot had largely ignored: the political implications." ${ }^{20}$ In this article, I will add a more significant novelty to Rousseau's address of the relationship of language to legislation. Rousseau did not just describe this lost language-I believe he used it himself.

The "figurative" language that Rousseau finds described in Warburton's Divine Legation as "the uniform voice of nature" ${ }^{21}$ is that same language that Rousseau claims the lawgiver must use to persuade without convincing. Warburton grounds Moses' path to leadership in a lengthy account of the history of language and writing, which is, Warburton claims, "a gradual and easy descent from a picture to a letter." ${ }^{22}$ Tracking the imagined transformation of Egyptian hieroglyphs (pictures) into an alphabet proper, Warburton claims to show that the original hieroglyphic language was "highly figurative and full of material images; so that, when men first thought of recording their conceptions, the writing would be, of course, that very picture which was before painted in the fancy." ${ }^{23}$ This is also precisely what Rousseau argues in his Essay on the Origin of Languages: "figurative language [langage figuré] arose first, proper meaning [le sens propre] was found last ... At first men spoke only poetry; only much later did it occur to anyone to reason"; "the figurative word arises before the proper word does, when passion holds our eyes spellbound." ${ }^{24}$ This is why, Rousseau claims, the first language would "persuade without convincing, and depict without arguing." 25 With the appearance of this phrase in both the Essay and the Social Contract, Rousseau ties the lawgiver's persuasiveness to this particular kind of language: one that speaks passionately to the hearts of men because it is closest to the first original and universal language. As Rousseau writes in the Essay, "as enlightenment spreads, language changes in character; it becomes more precise and less passionate; it substitutes ideas for sentiments, it no longer speaks to the heart but to reason." 26

\footnotetext{
${ }^{20}$ Sophia Rosenfeld, A Revolution in Language: The Problem of Signs in Late Eighteenth-Century France (Stanford, 2001), 52, 48.

${ }^{21}$ Warburton, Divine Legation, 2: IV, 405.

${ }^{22}$ Ibid., 2: IV, 405.

${ }^{23}$ Ibid., 2: IV, 448.

${ }^{24}$ Rousseau, EOL III, 253; OC V, 381. Citations from the Essay on the Origin of Languages taken from The Discourses and Other Early Political Writings, ed. Victor Gourevitch (1997) (Cambridge, 2007). The French has also been consulted, cited as EOL, followed by the corresponding references to the Oeuvres completes in the form OC volume number, page number. Rousseau claimed that the Essay was a long extract that he had pulled from the Second Discourse, which was completed in 1754. Scholars feel comfortable placing the drafting of the essay in 1754-5, and the completion around the time of Emile's publication in 1762 . It was only posthumously published in 1781 .

${ }^{25}$ Rousseau, EOL IV, 256; OC V, 383, my emphasis.

${ }^{26}$ Rousseau, EOL V, 256; OC V, 384.
} 
As I will show, like many in the eighteenth century who engaged in linguistic "conjectural histories," 27 Rousseau describes this first language with visual cues and imagistic references. Figurative, pictorial language was seen as the persuasive language that does not depend on reason (or "convincing") for its effect. The dangerous side of this in politics perhaps emerges when Rousseau says, for example, that this figurative language "is not that of the truth ... [but is an] illusory image." 28 The lawgiver attending in secret to these figurative untruths seems ominous. In equal measure, however, I will argue that Rousseau is himself using illusory images in his work-what Warburton calls "speaking hieroglyphic[s]" of the prophetic style ${ }^{29}$ - to persuade us of things without convincing us that they are true.

After outlining the broad context of the theories of language surrounding Rousseau, and attempting to persuade the reader that Warburton was of particular relevance to Rousseau's own work, I will turn to my own analysis in which I present Rousseau's Second Discourse as a text employing visual imagery. ${ }^{30}$ Natural man in the Second Discourse is, I argue, a kind of prophetic vision that inspires the transformation of those who are persuaded by its "illusory image" of natural independence, freedom, and equality-qualities which no longer persist in our degenerate and corrupted civilizations. It is impossible, I think, to convince human beings rationally that this vision of ourselves is true, but it is plausible that a writer like Rousseau might persuade us that its image says something "original" about our human nature.

I also tie Rousseau's lawgiver in the Social Contract back to William Warburton, and return to the question of legislation and language. A significant aspect of Warburton's work in the Divine Legation is his refutation of the hypothesis that hieroglyphs were invented for the sake of secrecy and esotericism. Warburton instead claims that hieroglyphs only became the "alphabet for secrecy" over time, ${ }^{31}$ having first been the language closest to nature and to natural expression - "the first and most natural way of communicating." 32 Hieroglyphs were not "a device of choice for secrecy, but an expedient of necessity, for popular use."33 Over time, "one of the simplest and plainest means of instruction came to be converted into one of the most artificial." ${ }^{34}$ The Egyptian priests ended up using hieroglyphs for the highest mysteries only once the alphabetic script had come into use, when the originally universal imagistic writing was rendered mysterious and secretive. Rousseau's particular praise of Moses as a lawgiver who made out of a "wandering and servile troop a body politic, a free people," ${ }^{35}$ suggests, I argue, that

\footnotetext{
${ }^{27}$ Coined by Dugald Stewart, as discussed in Avi Lifschitz, Language and Enlightenment: The Berlin Debates of the Eighteenth Century (Oxford, 2012), 3.

${ }^{28}$ Rousseau, EOL III, 254; OC V, 383.

${ }^{29}$ Warburton, Divine Legation, 2: IV, 450.

${ }^{30}$ In this respect, I agree with John Scott's reading. As Scott argues, the Second Discourse is "an attempt to persuade and educate [the] reader to 'see' natural man." Rousseau "must persuade the reader of the plausibility of that image" so that s/he "will be able to imaginatively see natural man as a possibility." John T. Scott, Rousseau's Reader (Chicago, 2020), 77, 103, 124.

${ }^{31}$ Warburton, Divine Legation, 2: IV, 432.

${ }^{32}$ Ibid., 2: IV, 388.

${ }^{33}$ Ibid., 2: IV, 394.

${ }^{34}$ Ibid., 2: IV, 413.

${ }^{35}$ Jean-Jacques Rousseau, Considerations on the Government of Poland, in Rousseau, The Social Contract and Other Later Political Writings, ed. Victor Gourevitch (Cambridge, 1997), 180, OC III, 956.
} 
Rousseau is attempting to reinvigorate that ancient wisdom, found in Warburton, that is even older than the philosophy or law of ancient Greece: the ancient Egyptian art of figurative persuasion, as exercised by Moses-an Egyptian priest. ${ }^{36}$ In this respect, Rousseau's attention is on the language itself being persuasive, rather than on the content of the religion espoused.

If this was Rousseau's model, he then saw the need to himself work with the "secret" craft of imagistic persuasion, ${ }^{37}$ precisely because it was still the only mode of communication that maintained a connection to the original "uniform voice of nature." 38 When popular and persuasive, the image of natural man painted in the Second Discourse speaks to men's hearts instead of their minds. As removed as we are from the natural condition, the possibility remains for us to effect a transformation of our conditions toward the "two principal objects" that serve as the "greatest good of all" and the "end of every system of legislation"- "freedom and equality"; 39 but only if we are first persuaded that these are in fact the things we are, and thus ought to desire, by nature.

Indeed, my boldest claim is that I believe we have in one sense been persuaded. The world in which we hold that human beings are naturally free and equal is the world in which we have been affectively_and effectively_-swayed by the image that Rousseau provided in the Second Discourse, designed to persuade us that what we are by nature is not how we are in a corrupt and civilized state. There is, then, truth to Rousseau being a kind of political mythologist and prophet of the modern era. But this is not only evident in modernity's dangerous "prophetic nationalism(s)" or "fanaticisms"; it is everywhere that human beings imagine themselves to be free and equal, and also see that in the world they are not so. Freedom and equality persist as these "illusory images" of the Second Discourse. Rousseau in many ways succeeded in becoming, for us, the lawgiver of nature.

\section{To "persuade without convincing": the context}

In this first section I will outline Rousseau's claim that one can persuade without convincing, and address the scholarship pertaining to the political implications of this claim in the Social Contract, most of which centers on the persuasiveness of music for legislation. Shifting my own focus instead onto what Rousseau has to say in the Essay on the Origin of Languages about visual images-which he claims are linguistically prior to music, and closer to nature-I also address the wide contextual field into which Rousseau was writing in the eighteenth century, concerning debates about the persuasiveness of imagistic language (both the visual arts and poetry) and its capacity to move viewers or spectators. So too, as Avi Lifschitz has written, was Rousseau thrusting himself into debates about conjectural

\footnotetext{
${ }^{36}$ The three principal lawgivers Rousseau names in Poland are (in order) Moses, Lycurgus, and Numa. While Rousseau writes that the "same spirit guided all ancient Lawgivers and their institutions" (181; OC III, 958), they certainly used very different languages. Importantly, Helena Rosenblatt, Rousseau and Geneva, 258, highlights another notable, and praised, legislator in Rousseau's note in the discussion of the lawgiver: Calvin.

${ }^{37}$ Rousseau, SC II xii, 202; OC III, 394.

${ }^{38}$ Warburton, Divine Legation, 2: IV 405.

${ }^{39}$ Rousseau, SC II.xi, 200; OC III, 391.
} 
history, and wide Enlightenment efforts to establish the point of origin of language and "the emergence of human language and civilization [on] naturalistic terms." 40 Coming to a point of convergence with his (once regular) dinner partners, Condillac and Diderot, Rousseau emphasized that the specifically hieroglyphic, poetic, and imagistic "first" language was a kind of expressive language of action now forgotten in civilization with the "progress" of abstract thinking and logic.

It was not particularly unique at the time for Rousseau (or his friends) to think of language as endowed with what Aarsleff calls "rhetorical expressivism"; ${ }^{41}$ nor was it unique to imbue language with powers to move people through gestures or image conjuring, which stretches back in the rhetorical tradition to Quintilian and Cicero, and which was widely taught and discussed in France in books about both Latin and French rhetoric. ${ }^{42}$ I do want to establish in what follows, however, that Rousseau was uniquely preoccupied with how this linguistic theory translated into political transformative power. As Sophia Rosenfeld writes, Rousseau thought it necessary to restore "a lost language of primal eloquence," because "the return to freedom" must be accompanied by "the revival of language." This link between language and political reconstruction makes Rousseau's interest in Warburton especially important. For this reason, I take some time in the following section establishing to the highest degree of manageable certainty that Rousseau read Warburton's own text (or, that is, Malpeines's 1744 faithful translation into French of the section on hieroglyphics ${ }^{44}$ ), and was not relying on the many circulating secondhand restatements of the Divine Legation-for example, Condillac's appropriation of Warburton's argument in his Essai sur l'origine des connoissances

\footnotetext{
${ }^{40}$ Lifschitz, Language and Enlightenment, 4.

${ }^{41}$ Hans Aarsleff, "Philosophy of Language," in Knud Haakonssen, ed., The Cambridge history of Eighteenth-Century Philosophy (Cambridge, 2006), 451-95, at 452.

${ }^{42}$ Two important sources named by Aarsleff in "Philosophy of Language" are Bernard Lamy's La rhétorique, ou l'art de parler (1675), and Fénelon's Dialogues sur l'éloquence en général et sur celle de la chaire en particulaire (1718, written late seventeenth century). Citing Cicero and Quintilian, Fénelon wrote that "the 'action of the body' expresses the 'sentiments and the passions of the soul" which constitutes a universal language (Aarsleff, "Philosophy of Language," 457). In his Rhetoric and Truth in France (Oxford, 1972), 9, Peter France describes "classical rhetoric, exemplified notably by Aristotle, Cicero, and Quintilian," which involved "three duties of the orator: to instruct (docere), to move (movere), and to please (delectare)." Here the purpose was also to move and to persuade listeners or readers. So too was there an emphasis on images and imagination when classical rhetoric was picked up in seventeenth- and eighteenthcentury France (ibid., 29). France discusses many texts about rhetoric in his book; a few more notable examples include René Bary's La rhétorique française (1673), A. Arnaud's Réflexions sur l'éloquence (1700), and B. Gibert's La rhétorique (1730). As I will discuss further, when later authors (Condillac, Diderot, Rousseau) describe primitive expressions as gestural, or as communicating action and persuading, in one respect they are not saying anything particularly new. In another respect, however, they make an important departure when it comes to exploring the origin of language; that is, they begin to claim that there was (or is) a different kind of language (now forgotten) that can do this immediately, which is quite different to thinking or claiming that there are techniques in language already to effect these changes in listeners or readers (as is the case in rhetorical textbooks). In addition to what I recount in my summation of Rousseau's context in what follows, I will say more about the distinction of the persuasiveness of the first languages from "rhetoric" properly understood in my forthcoming contribution to Oxford University Press's Yasmin Solomonescu and Stefan H. Uhlig, eds., Persuasion after Rhetoric.

${ }^{43}$ Rosenfeld, Revolution, 52.

${ }^{44}$ Marc-Antoine Léonard de Malpeines, Essai sur les hiéroglyphs des égyptiens (1744). This is a translation of vol. 2, Bk IV of Warburton's Divine Legation.
} 
humaines. I believe it is independently worthwhile to establish that Rousseau would have been working with Warburton directly-this is a link that has thus far only been conjectural in scholarship on Rousseau-and it will also allow me to speak about arguments in Warburton's Divine Legation along with Rousseau's own corpus in full, including the important claims that Warburton makes about secrecy and priestcraft which do not appear in other works employing the Divine Legation (such as Condillac's Essai).

In the fourth chapter of his Essay on the Origin of Languages, Rousseau writes "Of the Distinctive Characteristics of the First Language" that "it would persuade without convincing, and depict without arguing." 45 Compared to the invocation of the same phrase in the Social Contract, the addition of "depicting" to the category of persuasive language is important. He writes,

I do not doubt that if it first existed, the first language would have preserved certain original characteristics besides vocabulary and syntax which would distinguish it from all other languages. Not only would all the turns of phrase in this language have to be in images, sentiments, figures; but in its mechanical aspect it would have to answer to its primary aim, and convey to the ear as well as to the understanding the almost inescapable impressions of passion seeking to communicate itself. ${ }^{46}$

It was, according to Rousseau, the "passions that wrung the first voices," and the first language would not be "methodical or reasoned" but "lively and figurative." 47

The first languages were those "of Poets", and they were "songlike and passionate before they were plain and methodical"; "at first men spoke only poetry; only much later did it occur to anyone to reason." ${ }^{38}$ It is passionate as opposed to reasoning, and thus persuades by moving men's hearts as opposed to convincing their minds: "as enlightenment spreads, language changes in character; it becomes more precise and less passionate; it substitutes ideas for sentiments, it no longer speaks to the heart but to reason." ${ }^{\prime 9}$

Political philosophers who have discussed the relation between the Essay and the Social Contract have almost exclusively focused on the musical emphases in Rousseau's account of language. Bryan Garsten writes, for example, that the lawgiver would have to employ "a primitive, musical, and melodious sort of speech that would provide immediate access to prerational sources of communal feeling." 50 John Scott writes, "speech and song are the expression of the developing moral passions. Rousseau argues that the first language, the archetypal form, was animated by the melodic accent of the passions, and as such it would have been sung rather than spoken." ${ }^{51}$ Tying the universality of language to the sonorous "cry of nature" that Rousseau discusses in the Second Discourse, Scott demonstrates that music and

\footnotetext{
${ }^{45}$ Rousseau, EOL IV, 256; OC V, 383.

${ }^{46}$ Rousseau, EOL IV, 255; OC V, 382-3.

${ }^{47}$ Rousseau, EOL II, 252; OC V, 380.

${ }^{48}$ Rousseau, EOL II, 253; OC V, 381.

${ }^{49}$ Rousseau, EOL V, 256; OC V, 384.

${ }^{50}$ Garsten, Saving Persuasion, 57.

${ }^{51}$ Scott, "Melodious Language," 808.
} 
melody are linked to the distinctively human exercise of language in the exhibition of moral passions. Different nations take on different melodies, and Scott argues that some melodies are more or less conducive to human freedom.

Invoking Rousseau's contribution to the Dictionary of Music, Scott cites Rousseau's discussion of ancient Greece: "laws and songs bore the same name in those happy times; they maintained unison in all voices, passed with the same pleasure into all hearts." ${ }^{52}$ Both the aspirational uniformity of the general will, and the role of the lawgiver, come into focus in Scott's analysis as consequences of the ability to persuade without convincing. He agrees with both Christopher Kelly and Jean Starobinski that "Rousseau's legislator is a musical legislator." ${ }^{53}$ Kelly writes that Rousseau's enduring interest in music (both in theory and in practice, as he was a writer of operas) was "transformed by his discovery that 'everything pertains radically to politics": "If imitative music is the most effective means for transporting people outside of themselves and inspiring them with appropriate feelings, it seems as if it should be the favored medium for the legislator's persuasion." 54

Scholars thus focus on Rousseau's argument for legislative or political persuasion in relation to musicality due to its power to move people, to speak to the passions instead of reason, and its seeming ancient relationship to law. All that can be said of music in this case, however, can also be said of Rousseau's accounting of and for visual images: that they are linguistically original, that they are figurative, that they speak to the heart and the passions, and that they can move. For Rousseau, in fact, in all cases the image is prior to music: 55 "Ancient history," Rousseau writes, demonstrates that the first language was "filled with ways of addressing arguments to the eyes"; ${ }^{56}$ and "all the turns of phrase in this language would have to be in images, sentiments, figures." ${ }^{n 7}$ Rousseau points toward the most ancient form of expression, found in ancient Egypt-itself also prior to the ancient Greek world: "the first way of writing is not to depict sounds but the objects themselves, either

\footnotetext{
${ }^{52}$ Ibid., 821.

${ }^{53}$ Ibid, 825. See Kelly, "To Persuade without Convincing"; Jean Starobinski, La remède dans le mal: Critique et legitimation de l'artifice à l'âge des Lumières (Paris, 1989). See also Brent Edwin Cusher, "A Master of the Art of Persuasion: Rousseau's Platonic Teaching on the Virtuous Legislator," in Cusher, On Civic Republicanism: Ancient Lessons for Global Politics (Toronto, 2016), 226-45. Also see forthcoming work(s) from Nina Valiquette Moreau.

${ }^{54}$ Kelly, "To Persuade without Convincing," 328, 329.

${ }^{55}$ In what follows, I will be drawing a distinction in my analysis between the "visual" and the "musical"something to which I will return in the conclusion when discussing the consequences for legislation in Rousseau's thought. It should be noted, however, that drawing such a hard distinction between the two - music and images-is in fact difficult in Rousseau's account of language. Consider, for example: "In a melody, sounds act not only as sounds but as signs of our affections, or our sentiments; this is how they arouse in us the [e]motions which they express and the image of which we recognize in them" (EOL XV, 288; OC V, 417). What I aim to do here is to extract Rousseau's discussion of images in the same manner that others have extracted what he has said about music, prioritizing the image over sound. This is all while maintaining that the relationship between the two is perhaps more symbiotic than this method would suggest.

${ }^{56}$ Rousseau, EOL I, 249; OC V, 376.

${ }^{57}$ Rousseau, EOL IV, 255; OC V, 382-3.
} 
directly as did the Mexicans, or by allegorical figures, as the Egyptians formerly did."

Rousseau's invocation of the first visual language, his emphasis on its persuasiveness and capacity to move, and his attention to historical linguistics, place him in significant company with other eighteenth-century French philosophes when addressing the origin and expressive use of language. The Abbé Du Bos embraced the visual and poetic powers of language in his Réflexions critiques sur la poésie et sur la peinture (1719). Taking a departure from Quintilian-who spoke well of teaching men the art of persuasion, but was mistaken in putting painting and rhetoric in competition ${ }^{59}$ - Du Bos embraces the "poetic style" in which "we are ravished with the images in which the poet expresses himself ... which strikes our imagination. ${ }^{\prime 60}$ He writes,

the art of moving and persuading mankind consists principally in knowing how to make a good use of these images. The very severest writer, who professes most seriously, that he intends to employ nothing but plain reason to convince us, soon finds, that to carry his point he must move us; and that, for this end, he must set before us the pictures of the objects he treats of. ${ }^{61}$

Even further, Du Bos claims that painting has the greatest power to affect us, because it operates on us by seeing, and it "does not employ artificial signs, as poetry, but natural ones." 62

Many of Du Bos's arguments are repeated in Étienne Bonnot de Condillac's Essai sur l'origine des connoissances humaines (1746). Condillac claims that the source of linguistic style must have been the attempt to "copy the sensible image of the language of action" into a style of "virtual painting"; "at its origin, style was poetic because it began by painting ideas." ${ }^{63}$ Hans Aarsleff's work establishing Condillac as the center of the language debate in France has been highly influential. Aarsleff claims that many, including Condillac (and Diderot, Maupertius, Rousseau), observed that "an entire thought is instantaneous, like a painting; it has no succession in time." ${ }^{64}$ Searching for the origin was an attempt, Aarsleff writes, to find that immediacy in language, "to get down to basic principles, to what is by nature as opposed to what is by art." ${ }^{\text {"65 }}$ Avi Lifschitz writes the same about the "Enlightenment effort" to locate the origin of language, which was "to distinguish the arbitrary or artificial signs from natural cries and gestures."

\footnotetext{
${ }^{58}$ Rousseau, EOL IV, 256; OC V, 384.

${ }^{59}$ All citations of Du Bos are of Abbé Du Bos, Critical Reflections on Poetry, Painting and Music, trans. Thomas Nugent (London, 1748) (based on the fifth revised edn of Du Bos), vol. 1, 31. The French was also consulted: Abbé Du Bos, Réflexions critiques sur la poésie et sur la peinture (1719) (Paris, 1740).

${ }^{60} \mathrm{Du}$ Bos, Critical Reflections, 232.

${ }^{61}$ Ibid., 234.

${ }^{62}$ Ibid., 321.

${ }^{63}$ Étienne Bonnot Condillac, Essay on the Origin of Human Knowledge, trans. Hans Aarsleff (Cambridge, 2001), 150. Condillac, Essai sur l'origine des connoissances humaines (Paris, 1746).

${ }^{64}$ Aarsleff, From Locke to Saussure, 157.

${ }^{65}$ Ibid., 159.

${ }^{66}$ Lifschitz, Language and Enlightenment, 2.
} 
Lifschitz argues that Aarsleff overstates Condillac's influence considerably (Aarsleff claims that Condillac "created the problem of the origin of language" ${ }^{\text {"67 }}$ ), especially obscuring the vast influence of Epicurus and Lucretius, who supplied ancient naturalistic accounts of language development embedded in historical narratives. ${ }^{68}$

In these Epicurean conjectural histories, language emerged and progressed over time-and it was Diderot, Lifschitz claims, who flipped this "civilizational narrative," "arguing that the so-called natural order was much closer to the primordial language of action rather than to modern French." ${ }^{69}$ Diderot writes in his Lettre sur les sourds et muets (1751) that "by over-refining we have impoverished our language," ${ }^{\prime 70}$ and emphasizes the immediacy of the visual and its supreme persuasive effect: "the painter who can express but a moment in time has not been able to represent so many symptoms of dissolution as the poet, but they are much more affecting; the painter shows us reality, whereas the expressions of the poet and the musician are but symbols." ${ }^{\text {"1 }}$ This lament for the lost capacity to move or persuade people once language had progressed to its civilized form is echoed in Rousseau's Essay: "as enlightenment spreads, language changes in character; it becomes more precise and less passionate; it substitutes ideas for sentiments, it no longer speaks to the heart but to reason." 72

When Rousseau claimed that the first language was that of poets, that it was both visual and passionate, and that it would have been lively with figures and sentiments, he was therefore not without precedent and reflected a large current of thought in eighteenth-century theories of language. ${ }^{73}$ I claim that we can see best where Rousseau starts to emerge distinct from his contemporaries by turning

\footnotetext{
${ }^{67}$ Aarsleff, From Locke to Saussure, 199.

${ }^{68}$ Lifschitz, Langauge and Enlightenment, Ch. 1. Rosenfeld, Revolution in Language, 35, also writes that the search for the origin of language in this period was launched by a "radical question once posed by the Epicureans: could one give a 'natural' explanation of the origin of language?" Lifschitz argues persuasively that Aarsleffs own strong emphasis on Condillac obscured the much wider debates occurring-Lifschitz's own focus is on the Berlin debates. For more on the "Epicurean" reading of Rousseau in particular see also Christopher Brooke, "Rousseau's Second Discourse: Between Epicureanism and Stoicism," in Christine McDonald and Stanley Hoffmann, eds., Rousseau and Freedom (Cambridge, 2010), 44-57; Jared Holley, "Rousseau's Refined Epicureanism and the Problem of Modern Liberty," European Journal of Political Theory 17/4 (2018), 411-31.

${ }^{69}$ Lifschitz, Language and Enlightenment, 34.

${ }^{70}$ Citations of Diderot from Denis Diderot, "Letter on the Deaf and Dumb for the Use of Those Who Hear and Speak," in Diderot's Early Philosophical Works, trans. Margaret Jourdain (Chicago and London, 1916), 158-225, at 213. Diderot, Lettre sur les sourds et muets (1751, published anonymously).

${ }^{71}$ Diderot, "Letter on the Deaf and Dumb," 212.

${ }^{72}$ Rousseau, EOL V, 256; OC V, 384.

${ }^{73}$ In one way, too, Rousseau's claim that this first "language of action" would "persuade without convincing, and depict without arguing" (EOL IV, 256; OC V, 383) is in line with the common parlance. While the French verbs 'to persuade' and 'to convince' are now listed as synonyms, in the Academy's Dictionary of both 1694 and 1762 (my translations from the French follow), this was not the case. Convaincre invokes things being proven, acts according with the truth, or persons beings convinced of (or convicted based upon) what is verifiably true, while persuader has a much more active character: "our heart easily persuades us of what we want; he who persuades another to commit a crime is hardly less guilty than he who commits it." On the one hand, one is convicted of a crime (that is, the truth of the matter is settled); on the other, the emphasis is on the manner in which one can persuade another to commit a crime-the focus is on making another move, and so is a kind of "language of action."
} 
to what many acknowledge to be the urtext of the search for the origin of languages in the eighteenth century: ${ }^{74}$ William Warburton's Divine Legation of Moses (1737-41). The Divine Legation is a two-volume, nine-book, discussion of the relationship of divine revelation to politics, some portions of which were translated into French and widely circulated and read. The most influential segment of Warburton's work for the French philosophes was Marc-Antoine Léonard de Malpeines's 1744 translation of Warburton's history of writing, found in Volume II, Book IV, and published as the Essai sur les hiéroglyphs des égyptiens. ${ }^{75}$ The debts to Warburton in this period in France are so significant that Sophia Rosenfeld claims that "the fundamental French Enlightenment texts on the origin of language and the nature of gestural communication must be read, first, as elaborations of Warburton's model." ${ }^{76}$ Even Aarsleff-who claims that Condillac initiated the language origin debates-concedes that "Condillac was heavily indebted to one other English work [in addition to Locke's Essay], William Warburton's Divine Legation of Moses (1737-1741), where Condillac had found the doctrine of the language of action or gestures which occupies a crucial position in his argument."77

Condillac draws on Warburton extensively in his Essay. In the section on "Writing," Condillac includes a note specifying that almost none of his account is original, but replicates Warburton's arguments:

this section was nearly finished when I came upon the Essai sur les hiéroglyphs translated from the English of Warburton, a work equally informed by philosophical spirit and erudition. I was pleased to see that he and I agreed that language must at the beginning have been highly figurative and metaphorical. My own thoughts had also led me to observe that writing at first was merely a simple picture; but I had not yet tried to discover by what progress mankind had arrived at the invention of letters, and I found success hard to attain. This task has been perfectly accomplished by Warburton; from his work I have borrowed practically all I say about this subject. ${ }^{78}$

\footnotetext{
${ }^{74}$ Like Jean Starobinski, I believe that "Rousseau's originality depends not on isolated assertions, but on the correlations he sees and elaborates upon." Jean Starobinski, "Rousseau and the Origin of Languages," in Starobinski, Transparency and Obstruction, trans. Arthur Goldhammer (Chicago, 1971), 304-22, at 317. Rousseau is always both deeply in and significantly outside the sources he employs and the debates in which he is immersed.

${ }^{75}$ In all cases when I am citing the English I have consulted the French to confirm continuity; so too have I restricted myself to the portions that also appeared in French translation. If and when there is an addition or discrepancy I will note it.

${ }^{76}$ Rosenfeld, Revolution in Language, 40.

${ }^{77}$ Aarsleff, From Locke to Saussure, 148. Warburton is also the subject of an introduction/essay of Jacques Derrida's, "Scribble (Writing-Power)," Yale French Studies 58 (1979), 117-47. R. J. W. Mills has been doing interesting work recently, too, on eighteenth-century "Egyptomania" and the "Warburtonian school." See R. J. W. Mills, "Egyptomania and Religion in James Burnett, Lord Monboddo's 'History of Man'," History of European Ideas 47/1 (2020), 119-39; Mills, "David Hume and the Myth of the "Warburtonian School'," History of European Ideas, 11 Sept. 2020, at https://doi.org/10.1080/01916599.2020.1809004. Also see Cordula Neis, "European Conceptions of 'Exotic' Writing Systems in the Seventeenth and Eighteenth Centuries," Language and History 61/1-2 (2018), 39-51.

${ }^{78}$ Condillac, Essay, 178.
} 
Warburton is also cited and relied upon throughout the Encyclopédie's articles on language. Clifton Cherpack and James Doolittle have both done extensive work tracking Warburton's influence in "at least twenty-three" Encyclopédie entries by authors including Yvon, Diderot, d'Alembert, and Jaucourt. ${ }^{79}$ Warburton is invoked by Jaucourt in "Figure" (Volume 6,1756$),{ }^{80}$ for example, as an authority on the originally figurative nature of language:

if we judge by the monuments of antiquity, language was at first necessarily figurative ... In the first centuries of the world, conversation was maintained by speech intermingled with words and actions ... [Then] the use of hieroglyphs helped to make the style more and more figurative ... The same thing has happened in the art of speech ... One has only to read in M. Warburthon $[s i c]$ the ingenious parallel he makes between the apologue, the parable, the enigma, and the figures of language, on the one hand; and on the other, the different kinds of writings.

It is also via Warburton that we get poetic emphases on the "hieroglyphic" nature of the first language in Jaucourt (as above) and in Diderot, pointing both to the historical priority of the ancient Egyptian language in terms of development, and more symbolically to the ancient superiority of speaking in images. Diderot writes on the nature of persuasive language,

there is a spirit in the power's language which moves there and breathes life into each syllable. What is this spirit? I have felt its presence, but find it difficult to describe. I may say that it states and paints objects at the same time; it appeals not only to the understanding but to the soul which it stirs and the imagination that sees and the ear that hears. The lines are not merely chains of vigorous words which express the thought both forcibly and nobly, but a series of hieroglyphs, one after another, which picture the thought to us vividly. ${ }^{81}$

He also employs this turn of phrase to praise the "subtle hieroglyphs" of the ancients, Homer and Virgil. ${ }^{82}$

In the midst of this whirlpool of sources and intertextual exchanges, I believe that Warburton was an especially essential inspiration for Rousseau's work. The Divine Legation was not only a significant text in the search for an origin of language that was common to Rousseau and his interlocutors, but, for Rousseau specifically, it was the text that addressed how the "first" imagistic language that can

\footnotetext{
${ }^{79}$ Clifton Cherpack, "Warburton and the Encyclopédie," Comparative Literature 73/3 (1955), 226-39, at 227; James Doolittle, "Jaucourt's Use of Source Material in the Encyclopédie," Modern Language Notes 65/6 (1950), 387-92.

${ }^{80}$ Accessed via the ARTFL Encyclopédie: Denis Diderot and Jean le Rond d'Alembert, eds., Encyclopédie, ou dictionnaire raisonné des sciences, des arts et des métiers, etc., University of Chicago, ARTFL Encyclopédie Project (Aug. 2017 edn), ed. Robert Morrissey and Glenn Roe, at encyclopedie.uchicago.edu. Translations my own.

${ }^{81}$ Diderot, "Letter on the Deaf and Dumb," 194-5.

${ }^{82}$ Ibid., 197.
} 
move people can also serve to move people politically. Rousseau was attracted to the first visual language depicted in Warburton not only because of its emotive power, but also because the ancient Egyptian hieroglyphs served to promulgate the most ancient law-one that spoke to the heart instead of to reason through imagistic persuasion. Before moving into my interpretation of Rousseau's work in section III, in the next section II I will detail Warburton's arguments, and establish to the highest degree possible my confidence that Rousseau was drawing from Warburton directly.

\section{William Warburton's Divine Legation}

"The common foundation," Warburton claims, "of writing and speaking was a picture or image, presented to the imagination through the eyes and ears." ${ }^{" 83}$ This was a mode of communication that was "persuasive: for language was yet too narrow, and the minds of men too undisciplined, to support only abstract reasoning." 84 Focusing on hieroglyphs, Warburton claims that pictorial language corresponds to the communication of things, whereas alphabetical, or lettered, communication is always only the communication of words. ${ }^{85}$ The general history of writing is, then, "a gradual and easy descent from a picture to a letter"-that is, from figurative representation, to literal expression. There is such a concurrence in the first forms of communication throughout history and across cultures, Warburton claims, that this "method of recording the thoughts, can never be supposed the effect of chance, imitation, or partial purposes; but must needs be the uniform voice of nature."

The originality of pictorial representation-as in hieroglyphs-maps for Warburton onto an argument about the originality of figurative expression more generally. The use of pictures to communicate came to be transformed into the use of fables, into parables, and finally into metaphorical relations. Examples abound, Warburton claims, to demonstrate that all "common people are always most given to speak in figures" (here Warburton employs examples of the Iroquois, and also invokes Cicero-examples which are replicated in Condillac's Essay), and that figurative expression results from "gross conception $[\mathrm{s}]$ met with a warm imagination which delight $[\mathrm{s}]$ in painting strong and lively images." ${ }^{87}$ Hieroglyphs were, Warburton wants to demonstrate, not initially a secret and mysterious code, but part of a language that spoke to common people through imagistic communication: the universal voice of nature. This was, he claims, a "political alphabet" for popular use. ${ }^{88}$

It is only over the course of time that "hieroglyphs came to be employed for the vehicle of mystery" and used as an "alphabet for secrecy." "Warburton blames the Greeks for their misunderstanding of hieroglyphs: they saw the hieroglyph as a "representation of speculative notions of philosophy and theology; whereas it was

\footnotetext{
${ }^{83}$ Warburton, Divine Legation, 2: IV, 413, original emphasis.

${ }^{84}$ Ibid., 2: IV, 409.

${ }^{85}$ Ibid., 2: IV, 402.

${ }^{86}$ Ibid., 2: IV, 405, my emphasis.

${ }^{87}$ Ibid., 2: IV, 445-6. Here too we have another coming together of picture and sound, when Warburton claims that sounds in primitive languages would "incite the idea of the thing, sometimes as its audible image, sometimes as its natural representative.” Ibid., 2: IV, 440, my emphasis.

${ }^{88}$ Ibid., 2: IV, 440.

${ }^{89}$ Ibid., 2: IV, 417, 432, original emphasis.
} 
used only in public and open writings, to register civil policy and history." 90 As the Egyptologist Jan Assmann writes, supporting Warburton's analysis, hieroglyphs are often called "secret," but Assmann prefers "esoteric because they were not hidden but appeared everywhere." "W1 Warburton instead claims, citing Plato's Phaedrus, "that it was the first literary writing, not the first hieroglyphical, which was invented for secrecy. In the course of time, indeed, they naturally changed their use; letters became common, and hieroglyphs hidden and mysterious." 92 Once this transformation had taken place, Assmann writes, "it was simply understood that only those initiated into the mysteries could decipher them." 93

Warburton's main purpose in describing this transformation of the pictorial language into written is to analyze Moses' divine legation. Here, Warburton proposes that Moses altered writing even further because "all hieroglyphic writing was absolutely forbidden by the second commandment" as idolatry. ${ }^{94}$ "To cut off therefore all danger from symbolic images, Moses, as I suppose, altered the shapes of the Egyptian letters, and reduced them into something like those simple forms in which we now find them." 95 Assmann claims that Moses' example was one of "revelation as translation,"96 which turned away from the pagan idolatrous practice of speaking with images, and its presumed duplicitous language that dealt in mysteries and magic. Moses was nevertheless an Egyptian priest, and so Warburton saw "Moses' lawgiving and religious teaching [as] modeled on initiation into the greater and lesser mysteries of Egypt," understanding of the many modes of both open and secretive communication facilitated his "translation" of the word of God for the Israelites.

Assmann notes that Warbuton's reception in eighteenth-century philosophic circles had an unintended effect. The philosophes were not interested in Warburton's defense of divine legation; instead, they embraced the power of his account of pagan language: "Warburton came to substantiate the views of freethinkers and Freemasons, which he wanted to refute. The idea that pagan religions developed around a nucleus of original wisdom which they enshrined and sheltered in a complex and enigmatic structure of hieroglyphs ... had special appeal in the Age of Enlightenment." 98 They were also taken with Warburton's "evolutionary history" of "the gradual and easy descent from a picture to a letter." 99

Warburton brought this misreading upon himself. The "descent" from the natural to the artificial, and the picture to the letter, culminates for Warburton in a misunderstanding of hieroglyphic and pictorial writing. Thinking that hieroglyphs are in their origin secretive, mysterious, and idolatrous mistakes the hieroglyph in its "perverse corruption" for its essential and universal quality. ${ }^{100}$ We have been

\footnotetext{
${ }^{90}$ Ibid., 2: IV, 425.

${ }^{91}$ Assmann, Religio Duplex, 23.

${ }^{92}$ Warburton, Divine Legation, 2: IV, 428.

${ }^{93}$ Assmann, Religio Duplex, 24.

${ }^{94}$ Warburton, Divine Legation, 2: IV, 437.

${ }^{95}$ Ibid., 2: IV, 439.

${ }^{96}$ Jan Assmann, Moses the Egyptian (Cambridge, MA, 1997), 102.

${ }^{97}$ Ibid., 97.

${ }^{98}$ Ibid., 102.

${ }^{99}$ Assmann, Religio Duplex, 23; Warburton, Divine Legation, 2: IV, 403.

${ }^{100}$ Warburton, Divine Legation, 2: IV, 450.
} 
misled, Warburton claims, "by the Ancients themselves; some of whom imagined that the very first hieroglyphs were tainted with magical pollution." ${ }^{101}$ Instead, for Warburton, in its original, language was active and pictorial; and natural and universal in its imagery. Warburton claims to have shown in concluding this section of his Divine Legation that language was "highly figurative and full of material images; so that, when men first thought of recording their conceptions, the writing would be, of course, that very picture which was before painted in the fancy." 102 Indeed, if we are looking not for the language of revelation, but for a language that will reflect "the uniform voice of nature", ${ }^{103}$ Warburton has supplied a blueprint for its discovery and use. This is precisely what Rousseau saw, and he gravitated toward its persuasive power.

Now to the demonstration of why I believe Rousseau was drawing on Warburton directly. Given Warburton's saturation levels in French philosophic circles, this has seemed difficult to substantiate in the past. Clifton Cherpack claims, for example, that "there seems to be nothing in the Second discours or in the Essai sur l'origine des langues which indicates that Rousseau had more than an indirect knowledge of the bishop's [Warburton's] arguments filtered through Condillac," Legation of Moses? Nothing is less certain. In The Social Contract the name of Warburton is mentioned twice, but Rousseau does not refer to any specific work and his information could be just as well second hand."105

To begin, I am going to present two passages for comparison, with the mirrored structures italicized.

\section{a From Warburton's Divine Legation: ${ }^{106}$}

Profane antiquity is full of these examples; and it is not unlikely but, in the course of our enquiry, we shall have occasion to produce some of them: the early Oracles in particular frequently employed it, as we learn from an old saying of Heraclitus: That the king whose Oracle is at Delphi, neither speaks nor is silent, but reveals by SIGNS.

Now this way of expressing the thoughts by action perfectly coincided with that of recording them by PICTURE. There is a remarkable case in ancient story [Malpeines: j'ai remarqué dans une ancienne histoire une particularité ...],

\footnotetext{
${ }^{101}$ Ibid., 2: IV, 452.

${ }^{102}$ Ibid., 2: IV 448.

${ }^{103}$ Ibid., 2: IV, 405.

${ }^{104}$ Clifton Cherpack, "Warburton and Some Aspects of the Search for the Primitive in Eighteenth-Century France," Philological Quarterly 37/2 (1957), 221-33, at 232.

${ }^{105}$ Bronislaw Baczko, "Moise, législateur ...," in S. Harvey, M. Hobson, D. J. Kelley, and S. S. B. Taylor, eds., Reappraisals of Rousseau: Studies in Honour of R.A. Leigh (Manchester, 1980), 111-31, at 118-19, my translation.

${ }^{106}$ Warburton, Divine Legation, 2: IV 409.
} 
which shews the relation between speaking by action and writing by picture, so strongly, that we shall need no other proof of the similar nature of these two forms. It is told by Clemens Alexandrinus: They say, that Idanthura, a king of the Scythians (as Phercydes Syrius relates the story), when ready to oppose Darius, who had passed the Ister, sent the Persian a symbol instead of letters, namely, a mouse, a frog, a bird, a dart, and a plow. Thus this message being to supply both speech and writing, the purport of it was, we seen expressed by a composition of action and picture.

\section{b Rousseau in the Essay on the Origin of Languages: ${ }^{107}$}

What the ancients said in the liveliest way they expressed not in words but in signs; they did not say it they showed it.

Consult ancient history [ouvrez l'histoire ancienne vous la trouverez ...] ; you will find it filled with such ways of addressing arguments to the eyes ... The object presented before anything is said stimulates the imagination, arouses curiosity, holds the mind in suspense and anticipation of what will be said ... The most energetic speech is that in which the sign has said everything before a single word is spoken. Tarquin, Thrasybulus lopping off the heads of the poppies, Alexander putting his ring to his favorite's mouth, Diogenes walking in front of Zeno, did they not speak more effectively than with words? What circumlocutions would have expressed the same ideas equally well? Darius waging a war in Scythia receives from the King of the Scythians a frog, a bird, a mouse, and five arrows: the Herald transmits the gift in silence and departs. The terrible harangue was understood ...

It is the Darius example, and the surrounding context, that is most relevant here. First for the similarities: the Darius example that Rousseau uses to ground the imagistic origin of active language appears nowhere in Condillac or the Encyclopédie, nor in any other source that otherwise also invokes Warburton. Condillac in fact explicitly cites the beginning portion of the Warburton passage (the old saying of Heraclitus about the Oracle) but stops short of citing the rest. ${ }^{108}$ The skeptical reader might want to call this a coincidence. I think this is incredibly unlikely; but I also believe that the differences between Rousseau and Warburton's accounts signal that this is nearly impossible. You will notice a discrepancy. Warburton writes that there were five items-a mouse, a frog, a bird, a dart, and a plow-whereas Rousseau writes that there were four-a frog, a bird, a mouse, and five arrows. Warburton is drawing his account of Darius from Clement of Alexandria's Stromata (as told from the perspective of Idanthura, who is giving the items), and so recounts five items. The other account of this event comes in Herodotus' Histories, as told from the perspective of Darius receiving the items. In Herodotus, there are four named-a frog, a bird, a mouse, and five arrows (4.131); the same four that Rousseau includes.

\footnotetext{
${ }^{107}$ Rousseau, EOL I, 249; OC V, 376-7.

${ }^{108}$ Condillac, Essay, 117.
} 
This might seem to indicate a discontinuity, except that in Malpeines's translation of Warburton, he appends a lengthy note to the Darius story which I will here only quote in part. Malpeines writes (my translation and my emphasis): "Addition. The Persians were reduced, according to Herodotus, I.iv, to an extreme necessity, when the Scythians sent this message to Darius." Malpeines then faithfully recounts the full episode from Herodotus, noting the discrepancy between Clement and Herodotus: "If instead of fleeing, he said, like birds, you hide in the earth, or in water, like mice and frogs, you will perish by these arrows. For Herodotus, instead of a dart includes five arrows, and says nothing about the plow ... I thought it would please the reader to add this commentary by Herodotus to the Text of Pherecydes."

Avi Lifschitz also notes that Vico mentions the same Darius example in The New Science. ${ }^{109}$ I do not think it likely that Rousseau had read Vico ${ }^{110}$-but even if so, Vico himself names five items, not four, often mixing the two lists (from Clement and from Herodotus) together: "The king answered Darius the Great who had threatened to make war on him, with five real words"; 11 "In Northern Asia, Idanthyrsus, king of the Scythians ... used five real words to answer Darius the Great, who had declared war on him [Herodotus 4.131]. These five were a frog, a mouse, a bird, a ploughshare, and a bow" (note too that the reference to Herodotus cannot be correct if it names five instead of four). ${ }^{112}$

So to my mind there are two possibilities: (1) Rousseau read Malpeines's translation of Warburton and corrected to include Herodotus instead of Clement while replicating the structural relevance of its position in Warburton's argument about language in his own Essay, or (2) Rousseau independently read Herodotus' Histories (which of course he did) and not Malpeines's translation of Warburton, pulled this episode out (the context of which has nothing to do with language in the Histories), and inserted it into a contextually similar position in his own work to explain the "language of action" on almost identical terms to Warburton, even though he did not have Malpeines's Warburton.

The high degree of similarity of the passages around which the Darius examples appear in Malpeines's Warburton and Rousseau-as compared to the lack of such context in Herodotus, which has nothing at all to do with languages of action or picture-supports the first possibility named above. While it is the case that Rousseau independently read Herodotus' Histories, the likelihood that he would extract the same Darius story and place it in an almost identical context in his own argument about language when the Histories itself has no such discussion, without having read Malpeines's translation of Warburton, defies belief. The long corrective digression in Malpeines's translation drawing attention to precisely the

\footnotetext{
${ }^{109}$ Avi Lifschitz, "Ancient Performative Idiom," 60.

${ }^{110}$ Translators Max Harold Fisch and Thomas Goddard Bergin write in the extensively researched preface materials to The Autobiography of Giambattista Vico that there is no way to know for sure that Rousseau had read or heard of Vico. Max Harold Fisch and Thomas Goddard Bergin, "Vico's Reputation and Influence," in Giambattista Vico, The Autobiography of Giambattista Vico, trans. Max Harold Fisch and Thomas Goddard Bergin (Ithaca, 1963), 61-108, at 71. Vico is also nowhere mentioned-to my knowledge-in any of Rousseau's published or unpublished writings, including his letters.

${ }^{111}$ Giambattista Vico, The New Science, trans. Thomas Goddard Bergin and Max Harold Fisch (Ithaca, 1994), Bk 1, Section 1, XXXVIII, 99.

${ }^{112}$ Vico, The New Science, Bk 2, Ch. 4, 435.
} 
Herodotus example not named in Warburton's own work, and the lack of connection to Vico or to Vico's mixed examples also lead me to conclude that Rousseau read Malpeines's Essai; thus I maintain that we can assert with some high degree of confidence that Rousseau was working with Warburton directly.

\section{Figurative foundations: moving hearts and moving politics}

When Rousseau read Warburton, I believe a different sphere of purpose came into view in the search for the origin of language. Like many of his contemporaries, Rousseau grounded the first language in imagistic communication, and affirmed its inherent persuasiveness-but unlike his contemporaries, Rousseau saw the potential for this, in the words of Warburton, to be a transformative "political alphabet." ${ }^{" 13}$ Rousseau replicates the description of this lost first language in the Essay on the Origin of Languages as one that speaks to the heart, and can persuade without convincing, in his account in the Social Contract of the power that the lawgiver must exercise: he must be able to "persuade without convincing," attend to a law that will be "engraved ... in the hearts of the citizens." ${ }^{115}$ This chapter on the lawgiver also concludes with Rousseau's direct citation of Warburton.

At one interpretive level, the debt to Warburton in Rousseau's discussion of the lawgiver could be seen as fairly simple: Warburton supplied one argument (of many) to Rousseau about the power of great legislators, like Moses, to use language and persuasion in consolidations of power. In the Essay, Rousseau seems to have been particularly interested in ancient legislation through object or allegory, bound to the first language: "the first way of writing is not to depict sounds but the objects themselves, either directly as did the Mexicans, or by allegorical figures, as the Egyptians formerly did." ${ }^{116}$ For Rousseau, there is a kind of "language of legislation" belonging to the ancients, which other scholars have identified with music, but which I have demonstrated thus far is equally bound to visual communication.

I want to go one step further in my interpretation. I believe that Rousseau was himself using this ancient legislative and persuasive language in his own work. Here, then, I take a departure from much of the contextual investigation that has preceded in order to interpret Rousseau's own project. The contextual backdrop remains integral, however, to setting the scene for this analysis. Through his embeddedness in these debates about the origin of language, Rousseau encountered many arguments about the persuasiveness of images. So too were he and his (then) friends, Diderot and Condillac, particularly interested in the historical trajectories of the degeneration of language's persuasiveness over time. The first language for Rousseau was uncorrupted: energetic, persuasive, and figurative. Drawing from Warburton, I believe that Rousseau also saw this first figurative language as "the

\footnotetext{
${ }^{113}$ Warburton, Divine Legation, 2: IV, 440.

${ }^{114}$ Rousseau, SC II vii, 192-3; OC III, 383.

${ }^{115}$ Rousseau, SC II xii, 203, 202; OC III, 394.

${ }^{116}$ Rousseau, EOL IV, 256; OC V, 384.
} 
uniform voice of nature", ${ }^{117}$ and thus it was naturally suited for political transformation-like hieroglyphs for Warburton, which were "an expedient of necessity, for popular use" as "the first and most natural way of communicating."118

Rousseau, I argue, used this natural, imagistic language of legislation himself, in an attempt to effect a transformation of peoples' hearts away from their own corruption. The "unshakeable keystone" of any legitimate state, ${ }^{119}$ for Rousseau, is the figurative foundation he himself supplies in the Second Discourse: the image of natural man who, as "the uniform voice of nature", ${ }^{120}$ has the capacity to enact a transformation in persuading people that they are, by nature, free. This is Rousseau's "speaking hieroglyphic", 121 and his use of the ancient language that has been lost to the European civilized world. As Céline Spector writes, Rousseau was well "aware that [an] ancient republic cannot be revived," but he "would keep trying to invent the proper device to prevent further corruption." ${ }^{22}$ In this "first language" of hieroglyphic persuasion, I think he found just the device he was looking for. As I will suggest in conclusion, I also think that Rousseau has basically succeeded in persuading us with his image.

Like Warburton, when Rousseau is explaining the first modes of communication in the Essay - which rely on sight, images, and visual communication-he employs examples. ${ }^{123}$ "Consult ancient history," he writes,

you will find it filled with such ways of addressing arguments to the eyes, and they never fail to produce a more certain effect than all the discourses that might have been put in their place. The object presented before anything is said stimulates the imagination, arouses curiosity, holds the mind in suspense and anticipation of what will be said ... But the most energetic speech is that in which the sign has said everything before a single word is spoken. ${ }^{124}$

For an example of this energetic speech, Rousseau invokes a story from Herodotus (see section II above) and supplements it with an imagination of his own to further explain the priority of the figurative:

A savage meeting others will at first have been frightened. His fright will have made him see these men as larger and stronger than himself; he will have called them Giants. After much experience he will have recognized that since these supposed Giants are neither bigger nor stronger than he, their

\footnotetext{
${ }^{117}$ Warburton, Divine Legation, 2: IV, 405.

${ }^{118}$ Ibid., 2: IV, 394, 388.

${ }^{119}$ Rousseau, SC II xii, 203; OC III, 394.

${ }^{120}$ Warburton, Divine Legation, 2: IV 405.

${ }^{121}$ Ibid., 2: IV, 450.

${ }^{122}$ Céline Spector, Rousseau (Cambridge, 2019), 15.

${ }^{123}$ Rousseau, EOL I, 249; OC V, 376.

${ }^{124}$ Rousseau, EOL I, 249; OC V, 376. Cf. Émile, in which the tutor's object is to teach the young Émile using only objects: "I take away the instruments of their greatest misery-that is, books." "[You must] apply yourself to keeping him always within himself and attentive to what touches him immediately." Ibid., 253, 255; OC IV, 357, 359. All references to Émile are to Jean-Jacques Rousseau, Émile, trans. Allan Bloom, in Rousseau, Collected Works, vol. 13, ed. Christopher Kelly and Allan Bloom (Hanover and Chicago, 2010). Corresponding references to Rousseau's Oeuvres complètes follow.
} 
stature did not fit the idea he had initially attached to the word Giant. He will therefore invent another name common both to them and to himself, for example the name man, and he will restrict the name Giant to the false object that had struck him during his illusion. This is how the figurative word arises before the proper [or literal] word does, when passion holds our eyes spellbound and the first idea which it presents to us is not that of the truth ... Since the illusory image presented by passion showed itself first, the language answering to it was invented first. ${ }^{125}$

Here Rousseau is invoking the dichotomy of persuasion and truth to emphasize the manner in which the first language was linked to the passions, and was imagistic, or figurative, and also mythic. This example of Rousseau's links to the very first things said in the Essay about the first gestural modes of communication, which rely on sight, images, and visual communication. The "object presented" to us here (the first men and their encounter with "themselves") also "stimulates the imagination, arouses curiosity, holds the mind in suspense and anticipation."126

In this fable of Rousseau's, he presents us with an account of men who, when they did not understand what they saw as similar to them, called other men Giants. This is demonstrative not only of the original manner in which language was employed at the service of the passions (fear of others), but also of the fact that figurative language is original insofar as it is founded on difference. ${ }^{127}$ We provide figurations to ourselves of things that we do not understand, and that we do not see as similar to us. It is this capacity to imagine outside ourselves that ties the origin of language to the origin of society for Rousseau: "he who imagines nothing feels only himself; in the midst of mankind he is alone."128

Whoever sees only a single object has no occasion to make comparisons. Whoever sees only a small number from childhood on still does not compare them, because the habit of seeing them deprives him of the attention required to examine them: but as a new object strikes us we want to know it, we look for relations between the objects we do know; this is how we learn to observe what we see before us, and how what is foreign to us leads us to examine what touches us. Apply these ideas to the first men, you will see the reason for their barbarism. Never having seen anything other than what was around them, they did not even know it; they did not know themselves. They had the idea of a Father, a son, a brother, but not of a man. ${ }^{129}$

\footnotetext{
${ }^{125}$ Rousseau, EOL III, 254; OC V, 381-2. For more on this fable see Victor Gourevitch, “The First Times' in Rousseau's Essay on the Origin of Languages," Graduate Faculty Philosophy Journal 11/2 (1986), 123-46.

${ }^{126}$ Rousseau, EOL I, 249; OC V, 376.

${ }^{127}$ This is emphasized in the work of Paul de Man, and much of what follows is in line with his reading of the compatibility of the Essay and the Second Discourse. See Paul de Man, Allegories of Reading: Figural Language in Rousseau, Nietzsche, Rilke, and Proust (New Haven and London, 1979), and de Man, "Theory of Metaphor in Rousseau's Second Discourse," Studies in Romanticism 12/2 (1973), 475-98.

${ }^{128}$ Rousseau, EOL IX, 268; OC V, 396.

${ }^{129}$ Rousseau, EOL IX, 268; OC V, 396.
} 
Figurative language is thus prior to other forms of communication precisely because our conceptions of those things outside ourselves must begin as illusory images: they are mythic (untrue) to our own understanding. To see things in their genuine form, Rousseau claims, we must begin with seeing them in images -and they present themselves to us as images of difference, representing our passions.

Rousseau also claims in the Second Discourse that we have found ourselves in a position in which we no longer know ourselves:

the most useful and the least advanced of all human knowledge appears to me to be that of man; and I dare say that the inscription on the Temple of Delphi [know thyself] alone contained a precept more important and more difficult than all the hefty books of the moralists ... Since all the progress of the human species continually moves it further from its primitive state, the more we accumulate new knowledge, the more we deprive ourselves of the means of acquiring the most important knowledge of all, and it is, in a sense, by dint of studying man that we have rendered ourselves incapable of knowing him. ${ }^{130}$

It is, thus, our reason, and our studying, for Rousseau that have made us incapable of knowing ourselves: we have become convinced that we know what is good for us, only to subject ourselves to miserable conditions and political inequalities. We must thus be persuaded that we do not know ourselves as well as we think we do.

For this, Rousseau employs the very language of persuasion upon which he elaborates in the Essay on the Origin of Languages, inspired by Warburton's "lively images." Rousseau presents to us a living painting that communicates the universal voice of nature in its "original": the image, or figuration, of natural man. The Second Discourse is an account of first origins that Rousseau maintains is hypothetical: it is the image of natural man and of "a state which no longer exists, which perhaps never did exist, which probably never will exist, and about which it is nevertheless necessary to have correct notions in order to judge our present state properly." ${ }^{31}$ It is a fable that "speak[s] directly through the voice of nature."132 This presentation of natural man is not meant to be true; it can only serve to persuade. It moves us by virtue of being an image that is, to our civilized eyes, unrecognizable: it can only be a picture or a figuration-a new image that is designed to strike and move us. Like those first men who saw only giants, so too do we need to be made different to ourselves in order to know ourselves: "When one proposes to study men one has to look close by; but in order to study man one has to learn to cast one's glance afar; one has to begin by observing the differences in order to

\footnotetext{
${ }^{130}$ Rousseau, SD, 51-2; OC III, 122. For more on how Rousseau thinks we ought to "know ourselves" also see my account of the influence of Buffon and natural science on Rousseau's Second Discourse: Emma Planinc, "Homo Duplex: The Two Origins of Man in Rousseau's Second Discourse," History of European Ideas 47/1 (2020), 71-90.

${ }^{131}$ Rousseau, SD, 52; OC III 123.

${ }^{132}$ Rousseau, SD, 54; OC III, 125 . The movement of a figurative origin to a reasoning state is also replicated in Émile. Cf Bk II: "Before the age of reason, the child receives not ideas but images." Rousseau, Émile, 243; OC IV, 344.
} 
discover the properties." ${ }^{133}$ Rousseau thus concludes the Second Discourse placing savage and civilized man in such stark contrast that he claims they "differ so much in the bottom of their hearts and inclinations that what constitutes the supreme happiness of the one would reduce the other to despair."134 "Original man" is our natural condition, and we can only be persuaded of this if we are presented with the illusory image of how different we are from ourselves. ${ }^{135}$

This image, for Rousseau, can only serve to persuade if it does not attempt to convince. It is a corrective to the lack of poetic language in modernity, which Rousseau locates in a historical error: "once Greece abounded in Sophists and Philosophers it no longer had famous poets or musicians. In cultivating the art of convincing, the art of moving was lost." ${ }^{136}$ Rousseau is activating the ancient wisdom, even older than the philosophy of ancient Greece: the ancient Egyptian art of figurative persuasion. Maintaining a connection to Warburton's imagistic language that was "the first and most natural way of communicating", ${ }_{137}$ Rousseau is "speaking hieroglyphic[s]" in the prophetic style, ${ }^{138}$ "secretly" attending to the transformation of the human heart that must occur before there can be transformation in law. We must be moved to transform ourselves. ${ }^{139}$ This figurative foundation is the "unshakable keystone" of any legitimate state. ${ }^{140}$ To paraphrase the first chapter of Rousseau's Social Contract, man must be persuaded that he is born free, if he is to see that everywhere he is in chains.

Rousseau's focus on the image in the Essay therefore sheds new light on what Rousseau means when he says in the Social Contract that a lawgiver must "persuade without convincing." Most scholars who have worked on this phrase have focused on the musical elements of this "nonrational" mode of communication, arguing

\footnotetext{
${ }^{133}$ Rousseau, EOL VIII, 266; OC V, 394. See here also John Scott's "Do You See What I See? The Education of the Reader in Rousseau's Emile," Review of Politics 74/3 (2012), 443-64. Scott's article is an address of how Rousseau conjures up the image of the imaginary pupil in Émile in an effort to persuade (445-6), and to "visualize the world anew" (448). There are also interesting parallels between the argument I present here and Scott's "The Illustrative Education of Rousseau's Emile," American Political Science Review 108/3 (2014), 533-46.

${ }^{134}$ Rousseau, SD, 116; OC III, 192. Scott, Rousseau's Reader, 107, argues that Rousseau presents these two "types"-the savage and the civilized-into contrast at the end of the Discourse so that the image of natural man is put "into motion" by imagined interactions with civilized man in order to be "potentially persuasive."

${ }^{135}$ Michael Sonenscher has also highlighted the essential role of imagination in Rousseau's work in his Jean-Jacques Rousseau: The Division of Labour, The Politics of the Imagination, and the Concept of Federal Government (Leiden, 2020). He writes that the imagination is at the center of Rousseau's Second Discourse, and that "once ignited, the imagination [has] the power to compel people to feel as strongly about something moral as something physical." Ibid., 102.

${ }^{136}$ Rousseau, EOL XIX, 295-6; OC V, 425. Cf. Émile: "in neglecting the language of signs that speak to the imagination, the most energetic of languages has been lost ... It is with this language that one persuades and makes others act." Rousseau, Émile, 490; OC IV, 645).

${ }^{137}$ Warburton, Divine Legation, 2: IV, 388.

${ }^{138}$ Ibid., 2: IV, 450.

${ }^{139}$ See also Martin McCallum, who argues in his study of Emile that "Rousseau invites the reader to long for social and active connection ... It is an active, rather than a passive and idiosyncratic form of thinking" that Rousseau identifies in a nostalgic longing for nature. Martin McCallum, "Eyes Turning towards the Light: Nostalgic Memory and Nascent Community in Rousseau's Emile," History of Political Thought 38/4 (2017), 681-711, at 682.

${ }^{140}$ Rousseau, SC II xii, 203; OC III, 394.
} 
that the passionate, sonorous qualities are conducive to the lawgiver's "secretive" methods. To conclude my "Warburtonian" analysis of Rousseau's politics in the Social Contract, I will to return to what Rousseau says about sound and image in his Essay on the Origin of Languages.

Sounds, Rousseau writes, are always "functions of relationships" but "the properties of colors are not." ${ }^{\text {"141 }}$ So too does Rousseau claim that "the realm of music is time, that of painting is space"; "color is absolute, independent, whereas every sound is for us only relative and distinct only by contrast ... By itself, sound has no absolute character by which it might be recognized ... Since the entire system can vary from low to high, every sound changes its rank and position in the system as the system changes in degree." ${ }^{142}$ Sounds also

need a moving agent, and in order for them to exist, the sounding body has to be set in motion. Sight here enjoys a further advantage: for the constant emanation [of light] from the stars is the natural agency by which sight is acted upon, whereas nature by itself engenders few sounds and, short of believing in the harmony of the heavenly spheres, living beings are needed to produce it. Painting is thus seen to be closer to nature, while music is more closely related to human art. ${ }^{143}$

In this abstract discussion of image and sound, Rousseau is saying much about his broader political science. Images speak to what is natural, permanent, unchanging, independent. Sounds reflect what is changeable in and over time; they are relational and relative, more closely related to human artifice. This is why Rousseau claims in the Essay that every nation has its own "sound"-its own music, language, and accent. What makes the particular character of a nation, including its form and legislation, is its "sound." ${ }^{144}$ But this sound, according to Rousseau, must be set in motion.

Thus I have argued that the language closest to nature-the figurative imagemust set the "sounding body" of the body politic in motion. ${ }^{145}$ It must persuade us that we can see ourselves not as corrupt, but as naturally free and equal. It does so, in Rousseau's Second Discourse, through presenting us with a differentnatural-image of ourselves that will set in motion the transformative action in our hearts before it becomes possible in the state, however a state's own sound or melody will be constituted in its particular time. As John Scott writes, Rousseau "must persuade the reader of the plausibility of [the] image" in order to "imaginatively see natural man as a possibility." "Th "This "illusory image" of our natural self is persuasive because Rousseau does not try to convince us of its truth; he attempts to make us desire its condition, in all its difference from the civilized corrupt state. One can only legitimately make law if people feel in their hearts

\footnotetext{
${ }^{141}$ Rousseau, EOL XVI, 291; OC V, 420.

${ }^{142}$ Rousseau, EOL XVI, 291; OC V, 420.

${ }^{143}$ Rousseau, EOL XVI, 292; OC V, 421.

${ }^{144}$ See John Scott, "Melodious Language."

${ }^{145}$ The phrase "sounding body" also appears in Condillac via Rameau: "Rameau is the first to have found the origin of all harmony in the resonance of sonorous bodies." Condillac, Essay, 139.

${ }^{146}$ Scott, Rousseau's Reader, 103, 124.
} 
that they are worthy of being subject to it, having freely made it themselves. This is the broad program of the Social Contract, in which Rousseau chooses to use a picture-an engraving-to describe the "secret" project of the lawgiver: the "genuine constitution of the state" must be "engraved ... in the hearts of the citizens."147 This is exactly how "men would have to be prior to the laws what they are to become through the laws." 148

It is the work of another article to properly establish the many connections between this analysis of the Essay, the Social Contract, and other political works of Rousseau's, but I hope that the reader will indulge some of my interpretive gestures here. While the image in all its energetic liveliness is the most persuasive, and also the "language" that is first and closest to nature, its effects are transformative but ultimately limited. As Rousseau recounts in his tale of the mistaken giants, figurative language arises first but it is not "proper" or "that of the truth." ${ }^{149}$ In order to reach outside ourselves, we require imagination-for "he who imagines nothing feels only himself; in the midst of mankind he is alone" ${ }^{150}$-but the first thing we are confronted with is difference, eradicating this "passion that holds our eyes spellbound" only when the "image" was transformed into its "proper" sense. ${ }^{151}$

While the Second Discourse is written in the language of images in order to have us see ourselves differently-to hold ourselves spellbound in confronting our own natures-the Social Contract seeks to establish the "proper" idea of man on the foundations of this radical self-realization through differentiation. It is an attempt to transform the "illusory image" of natural freedom and equality into an artificial association of "unanimity" in a general will, ${ }^{152}$ out of shockingly corrupt and unequal conditions. Now, as reasoning creatures of civilization, the possibility (however slim) remains open for us to strive for a legitimate social contract in which each remains free; to transform what was illusory into what is genuine, and what was once only individually persuasive into what could be universally true; to see what was once different from us as the same as ourselves. Rousseau gives us an idea of how this operates in his Considerations on the Government of Poland. "You love freedom," he writes, "you are worthy of it ... [and] weary of your fatherland's troubles you sigh for tranquility." "But no constitution will ever be good and solid unless the law rules the citizen's hearts ... But how can men's hearts be reached? This is something to which our founders, who never see anything but force and punishments, scarcely give a thought." "How, then, can one move hearts ... Dare I say it? With children's games; with institutions which appear

\footnotetext{
${ }^{147}$ Rousseau, SC II xii, 202; OC III, 394. Engravings were also very important to Rousseau when it came to producing the images that accompanied his texts (see John Scott on Émile's engravings, for example). I also think this is an intriguing difference from what Teresa Bejan highlights in Hobbes's work: the act of "imprinting" on men's minds. As Bejan writes, Hobbes's "method" is distinct from "Platonic plattein or Rousseauvian engraving": Teresa M. Bejan, "First Impressions: Hobbes on Religion, Education, and the Metaphor of Imprinting," in Laurens van Apeldoorn and Robin Douglass, eds., Hobbes on Politics and Religion (Oxford 2018), 45-62, at 62.

${ }^{148}$ Rousseau, SC II vii, 192-3; OC III, 383.

${ }^{149}$ Rousseau, EOL III, 254; OC V, 381.

${ }^{150}$ Rousseau, EOL IX, 268; OC V, 396.

${ }^{151}$ Rousseau, EOL III, 254; OC V, 381.

${ }^{152}$ Rousseau, SC I v, 172; OC III, 359.
} 
trivial in the eyes of superficial men, but which form cherished habits and invincible attachments"153 - that is, with the imagination to change what you, and others, will see. It is also in his Considerations on the Government of Poland that Rousseau lauds Moses for his power to make out of a "wandering and servile troop a body politic, a free people."

Legislation and the Social Contract only stand when we have first heard the voice of nature through Rousseau's original, imaginative moving picture, when we have seen ourselves differently and have been persuaded to desire our natural freedom and equality-the "two principal objects" that serve as the "greatest good of all" and the "end of every system of legislation."155 Inspired by that ancient Egyptian mode of legislating by image, Rousseau was the lawgiver of nature. To be persuaded without being convinced, then, is not the nefarious enterprise it first appears to be. It is at the foundations of coming to know who and what we are as linguistic, political, and human beings. Indeed, we now hold as true and self-evident that we are free and equal, which according to-or because of-Rousseau we must, I think, acknowledge to be an image or figuration. Rousseau's seeming rejection of truth and embrace of the nonrational cannot be the source of a wholesale condemnation of his politics. We need to see, rather, that these figurative foundations are precisely what provides the power to inspire people to act, to move people: that this provides an image of what we are not. The ground of the Social Contract, in its liberal iterations as well as in its more frightening nationalistic ones, is a figuration of the human being that did, and does still, serve to persuade and move people politically, whether for good or for ill.

Acknowledgments. My great thanks to Darrin McMahon for his support and editorial guidance, the co-editors of Modern Intellectual History, managing editor Tiraana Bains, and to the anonymous reviewers who made this article better. I also owe deep gratitude to John Scott for his support and comments throughout the development and completion of the piece, and many thanks to Arash Davari, Scott Dodds, and Martin McCallum for their detailed and helpful readings of earlier iterations. Previous versions of this paper were presented at the Persuasion after Rhetoric conference at Notre Dame, ISSEI 2019 and APSA 2019, and the Stanford University History of Political Thought Workshop 2020. For their invitations to present, and thoughtful engagements with this work (as organizers or participants), I thank especially Teresa Bejan, Eileen Hunt, Alison McQueen, Dirk Schuck, Avshalom Schwartz, Torrey Shanks, Yasmin Solomonescu, Alicia Steinmetz, Stefan Uhlig, and Ann Ward. I am also very grateful to my grad students in our Rousseau seminar at Notre Dame, who pushed me to rethink Rousseau in new ways, and helped this paper see its final form.

\footnotetext{
${ }^{153}$ Rousseau, Poland, 179, my emphasis; OC III, 954-5.

${ }^{154}$ Rousseau, Poland, 180; OC III, 956. Here, perhaps, a doubling of how a free people could be made from the Second Discourse: from the natural men wandering in the forest, and the servile, corrupt men of modern Europe.

${ }^{155}$ Rousseau, SC II.xi, 200; OC III, 391.
}

Cite this article: Planinc E (2023). The Figurative Foundations of Rousseau's Politics. Modern Intellectual History 20, 1-26. https://doi.org/10.1017/S1479244321000688 